\title{
Large Libraries and Information Desks
}

The results of a survey on the nature and functions of information desks in large academic and public libraries are examined with respect to the functions, staffing patterns, and times of service of information desks. Various aspects of the structure of libraries are analyzed in relation to information desk services with some differences in services found between academic and public libraries. The survey expands and brings up to date Kleiner's 1967 study.

\section{INTRODUCTION}

Although there is consmerable litERATURE on various aspects of reference work, only one article seems to have been written specifically about the information desk. Jane P. Kleiner surveyed the member libraries of the Association of Research Libraries in 1967 regarding information desk services and reported her results and conclusions in the November 1968 issue of College and Research Libraries. ${ }^{1}$

To broaden the knowledge base concerning information desks, the author conducted a mail survey of large academic and public libraries in the spring of 1972. This survey included a wider range of topics than did Kleiner's and was mailed to a larger sample of libraries. In addition to a broad overview of information desk services, specific foci of the study were: (1) the nature of information desk work as practiced in large libraries, particularly the professional/nonprofessional dimensions of the job; (2) the influence that the structure of the library, with emphasis on the arrangement of its reference services, might have on the nature of information desk service; and (3) the

Larry E. Harrelson is director, Crowley Ridge Regional Library, Jonesboro, Arkansas. differences, if any, of information desk service in academic versus public libraries.

\section{METHODOLOGY}

Data were gathered by means of a three-page questionnaire mailed to 124 academic libraries and 73 public libraries in the spring of 1972. The sample consisted of all academic and public libraries with holdings of 500,000 volumes or more, according to the 1970 1971 American Library Directory. State libraries and special libraries were excluded from the sample.

Of the 197 questionnaires mailed, 155 were returned, for an overall return rate of 79 percent. For academic libraries, the return rate was 82 percent, and for public libraries, 73 percent. The following analysis is based on 102 usable questionnaires from academic libraries and 47 usable returns from public libraries. ${ }^{2}$

The returns were from a first and only mailing, and no follow-up letters were mailed. This relatively high return seems to reflect considerable interest in the matter. Many respondents indicated that information desks were a topic of interest and discussion in their libraries, and sixteen librarians explicitly requested that they receive a copy of the results.

Items on the three-page questionnaire 
required either a check mark or a short answer. Most of the third page was left empty for "additional comments." The definition utilized in the survey was an operational one:

Information Desk: a desk readily available to library patrons upon first entering the building. Traditional information desks have provided three basic types of service: (1) locational or directional information (where is $\longrightarrow$ ?), and (2) instruction in use of the library and its materials, and (3) simple reference. Catalog assistance may also be a function of the information desk. The information desk may be distinguished from a reference desk in that the reference service provided by the information desk is limited to simple or "ready" reference; it does not offer extensive or specialized reference assistance.

\section{InFormation Desks \\ AND THE STRUCTURE OF LIBRARIES}

Many large libraries do not have information desks: 53 percent of 102 academic libraries and 36 percent of 47 public libraries do not. In the libraries without information desks, the services that are usually performed by information desks are rendered by other library units. As expected, this unit most often is the reference department, although frequently the circulation department fulfills many of the functions.

A larger percentage of public libraries have information desks (64 per- cent) than do academic libraries (47 percent). This may indicate a greater service orientation of public libraries and less library sophistication of the average user.

A definite correlation occurs between the existence of an information desk and the existence of a decentralized system of reference (see Table 1). A chi square analysis shows the relationship to be significant at the .01 level for academic libraries and at the .10 level for public libraries.

A centralized reference service, if properly located, can assume most or all of the services of an information desk; when the reference service is decentralized, however, no other unit can easily perform the directional assistance, catalog assistance, and simple reference functions of the traditional information desk. Conversely, in a decentralized reference situation, a referral service is needed to advise the patron and to refer him to the appropriate subject reference specialist.

Although it was assumed that systems with a large number of branch libraries might have more need of an information desk in the main library (to explain the library system to patrons and to refer patrons to the appropriate branch), this was not the case. Academic libraries-with or without an information desk-have about the same number of branches. The lack of a relationship may be due to the small number of

TABLE 1

Structure of Reference Service and Presence of Information Desks

\begin{tabular}{lcccr}
\hline \hline & $\begin{array}{c}\text { Number Having } \\
\text { a Centralized } \\
\text { Reference Area }\end{array}$ & $\begin{array}{l}\text { Number Having } \\
\text { a Decentralized } \\
\text { Reference Area }\end{array}$ & $\begin{array}{c}\text { Nonresponses } \\
\text { to This Item }\end{array}$ & Total \\
\hline $\begin{array}{l}\text { Academic Libraries with Information } \\
\begin{array}{c}\text { Desks } \\
\text { Academic Libraries without Information } \\
\text { Desks }\end{array}\end{array}$ & 18 & 26 & 4 & 48 \\
\hline \hline $\begin{array}{l}\text { Public Libraries with Information Desks } \\
\text { Public Libraries without Information } \\
\text { Desks }\end{array}$ & 1 & 17 & 0 & $\mathrm{~N}=\mathbf{1 0 2}$ \\
\hline
\end{tabular}


branches in most academic systems (the median being approximately five branches).

Public library systems tend to have more branch libraries than do academic ones. In addition, public libraries with information desks in the main library appear to have more branches than those without information desks. Yet this correlation cannot be explained on the grounds that an information desk is needed for the large number of branch libraries because public library branches are, in essence, small public libraries, not subject speciality libraries (as in academic libraries); and because this correlation may only reflect that the entire system, including the main library, is large and complex.

Another way of examining the relationship between the structure of libraries and information desks is through the existence of catalog assistance and general reference desks. It was hypothesized that a general reference desk would not be needed if there were an information desk (except perhaps in a library with centralized reference), and that a catalog assistance desk would not be necessary if the information desk were near enough to the catalog to perform that function. The data did not support these speculations. Sixty-six percent of the academic libraries with information desks and 47 percent of the public libraries with information desks, in addition, staff general refer- ence desks. Twenty-seven percent of the academic libraries and 50 percent of the public ones with information desks also have catalog assistance desks. Apparently some libraries receive so many general reference and catalog assistance questions that the information desk cannot both answer them and perform its directional function properly.

\section{Times of Information Desk Service}

The libraries with information desks vary considerably in the amounts of time that the desk is staffed. Table 2 indicates the diversity. Both academic and public libraries staff their information desks about the same number of hours per week (cf. mean hours). However, since academic libraries on the average are open more hours per week than are public libraries, the ratio of time that the information desk is staffed to time that the library is open is smaller for the academic libraries. Twenty-nine of the thirty public libraries staff their information desks 100 percent of the time that the library is open (up to 71 hours per week), and twelve of the fortyeight academic libraries staff their information desks 100 percent of the time that the library is open (up to 102 hours per week).

Of the forty-eight academic libraries, 98 percent staff the information desk during the day, 73 percent during evenings, and 73 percent on weekends. In the thirty public libraries, the informa-

TABLE 2

Information Desk Service Per Week

\begin{tabular}{lccc}
\hline \hline & $\begin{array}{c}\text { Number of Hours } \\
\text { Library Is Open }\end{array}$ & $\begin{array}{c}\text { Number of Hours Information } \\
\text { Desk Is Staffed }\end{array}$ & $\begin{array}{c}\text { Percentage of Time } \\
\text { Library Is Open } \\
\text { That Information } \\
\text { Desk Is Staffed }\end{array}$ \\
\hline $\begin{array}{c}\text { Academic Libraries } \\
\text { Range }\end{array}$ & $61.5-168$ & $18-102$ & $\mathrm{~N}=48$ \\
Median & 100 & 78 & $17.6-100$ \\
Mean & 99.1 & 69.9 & 82.8 \\
Public Libraries & $48-71$ & $48-71$ & 77.6 \\
Range & 67 & 67 & $\mathbf{N}=30$ \\
Median & 66.4 & 66.2 & $88.4-100$ \\
Mean & & & 100 \\
& & & 99.6 \\
\hline
\end{tabular}


TABLE 3

Functions of Information Desks

\begin{tabular}{lcc}
\hline \hline \multicolumn{1}{c}{ Function } & $\begin{array}{c}\text { Academic Libraries } \\
(\mathrm{N}=48) \\
\text { Number (Percent) }\end{array}$ & $\begin{array}{c}\text { Public Libraries } \\
(\mathrm{N}=30) \\
\text { Number (Percent) }\end{array}$ \\
\hline $\begin{array}{l}\text { Directional Information } \\
\text { Catalog Assistance }\end{array}$ & $48(100)$ & $30(100)$ \\
Instruction in use of periodical indexes & $42(88)$ & $23(77)$ \\
Instruction in use of bibliographies & $24(50)$ & $8(27)$ \\
Simple reference service & $24(50)$ & $8(27)$ \\
Answering mail requests & $34(71)$ & $16(53)$ \\
Giving library tours & $17(35)$ & $8(27)$ \\
Giving library instruction to classes, special groups, etc. & $20(42)$ & $5(17)$ \\
Telephone switchboard & $17(35)$ & $5(17)$ \\
& $14(29)$ & $5(17)$ \\
\hline
\end{tabular}

tion desk is manned during the day in all cases, during the evenings in 97 percent, and on weekends 97 percent. Most of the public libraries are closed on Sundays.

\section{Functions of InFORMation DESKS}

Table 3 presents an outline of the nature of information desk service in large academic and public libraries, as measured by this survey. Public libraries have a somewhat different profile than do academic libraries, particularly in instructional types of functions. All provide directional information service, telephone service, indexing current book reviews, directory service, screening applicants for library privileges, interlibrary loan assistance, check-out of special materials and filing.

Respondents were also asked to categorize information desk functions in terms of the three traditional areas of information desk service-directional information, instruction in use of the library and its materials, and simple reference-and to estimate the percentage of time spent in each area. As Table 4 suggests, most services performed by information desks can be subsumed under three headings. On the average, approximately half of information desk service consists of directional and locational assistance.

On a professional/nonprofessional basis, respondents varied considerably in their estimate of time spent on duties in each category. Some thought that none of the information desk duty was professional in nature, and some considered all the work professional. Academic and public libraries were similar in their average estimates of the percentage of time spent on professional duties: academic libraries had a median of 40 percent and a mean of 41.9 per-

TABLE 4

Percentage of Thme Spent on Directional Assistance,

LibraRy Instruction, and SMmple Reference

\begin{tabular}{lccc}
\hline \hline & $\begin{array}{c}\text { Directional Assistance } \\
\text { (Percent) }\end{array}$ & $\begin{array}{c}\text { Library Instruction } \\
\text { (Percent) }\end{array}$ & $\begin{array}{c}\text { Simple Reference } \\
\text { (Percent) }\end{array}$ \\
\hline $\begin{array}{c}\text { Academic Libraries } \\
\text { Range }\end{array}$ & $5-100$ & & $0-70$ \\
Median & 50 & 25 & $0-70$ \\
Mean & 48.3 & 26.8 & 18 \\
Public Libraries & $5-100$ & $0-70$ & 18.8 \\
Range & 50 & 15 & $0-70$ \\
Median & 49.5 & 19.6 & 17.5 \\
Mean & & & 22.3 \\
\hline
\end{tabular}


cent, and public libraries had a median of 45 percent and a mean of 42.6 percent.

Another way in which the nature of information desk service, particularly its service aspect, might be elucidated is to know the size of the reference collection kept at or near the information desk and utilized by desk attendants. Some information desks in the survey had no reference works at all at the information desk; at the other extreme, one public library had 10,000 volumes available for use by the information desk. The libraries fall into five groups based on the number of reference works normally available to the information desk:

\section{Number of Reference Volumes Academic Public}

1. None 10

2. A dozen or fewer 10

3. Between a dozen and a hundred 10

5

4. Between a hundred and a thousand

5. Over a thousand

$\begin{array}{rr}8 & 5 \\ 3 & 1 \\ N=41 & \mathrm{~N}=26\end{array}$

About two-thirds of both academic and public libraries have fewer than one hundred volumes at the information desk, which supports the idea that it is usually the "simple" or "quick" type of reference that is rendered at the information desk.
In addition to reference works kept at or near the information desk, frequently other materials are close enough to be used by the information desk attendant while working. Table 5 lists some of these tools and services and notes the percentage of libraries in which they are utilized by the information desk attendant.

Other materials or services mentioned include books-on-order file, telephone directories, information about the library, information about the university and/or city, college catalogs, shelflist, reserve desk, registration file, subject headings, vertical file, index to recent book reviews, and new book shelf.

\section{Staffing the Information Desks}

As Tables 6 and 7 depict, academic libraries tend to have a higher status person staffing the information desk during the day than do public libraries. The situation is reversed for evening and weekend hours, when public libraries staff the information desk with a higher status person.

Sixty-five percent of the academic libraries and 53 percent of the public libraries having information desks think that a professional librarian is needed at the information desk during the day. For evening and weekend hours, 56 percent of the academic libraries and 50 percent of the public libraries consider that a professional librarian is neces-

TABLE 5

Materials and Services Near Enough to the Information

Desk to Be of USE in Normal Information Desk Work

\begin{tabular}{lcc}
\hline \hline \multicolumn{1}{c}{ Item } & $\begin{array}{c}\text { Academic Libraries } \\
(N=48) \\
\text { Number (Percent) }\end{array}$ & $\begin{array}{c}\text { Public Libraries } \\
(N=30) \\
\text { Number (Percent) }\end{array}$ \\
\hline $\begin{array}{l}\text { Card catalog } \\
\text { Serials record }\end{array}$ & $42(88)$ & $22(73)$ \\
Periodical indexes & $35(73)$ & $18(60)$ \\
Bibliographies & $21(44)$ & $9(30)$ \\
Reference works other than the information desk & $27(56)$ & $11(37)$ \\
collection & $18(38)$ & $8(27)$ \\
Circulation desk & $36(75)$ & $13(43)$ \\
Interlibrary loan & $26(54)$ & $8(27)$ \\
\hline
\end{tabular}


TABLE 6

Staffing Patterns During Daytime Hours

\begin{tabular}{lcc}
\hline \hline & $\begin{array}{c}\text { Academic Libraries } \\
(N=48) \\
\text { Number (Percent) }\end{array}$ & $\begin{array}{c}\text { Public Libraries } \\
(N=30) \\
\text { Number (Percent) }\end{array}$ \\
\hline $\begin{array}{l}\text { Professional Librarian } \\
\text { High Level Nonprofessional }\end{array}$ & $35(73)$ & $19(63)$ \\
Low Level Nonprofessional & $11(23)$ & $10(33)$ \\
\hline
\end{tabular}

sary. In those libraries which do not staff the information desk with a professional librarian during evenings and on weekends, there is, almost without exception, a librarian on duty at some point in the library. In response to the question, "Would it be sufficient to have a librarian on call (in some other part of the building) to handle questions that a nonprofessional attendant could not answer?" 56 percent of the academic library respondents and 47 percent of the public library respondents said "yes."

Based on the data collected, the investigator concluded that in many, if not most, cases a professional librarian is not needed at the information desk (though it may be handy to have a librarian on call). The duties are basically subprofessional in nature. As noted in the discussion of information desk functions, approximately half of the staff time is devoted to directional assistance. Furthermore, much of the "library instruction" and "simple reference" service performed at an information desk does not require professional training. Elementary instruction in the use of a particular library, general peri- odical indexes, or the catalog can be handled by a trained nonprofessional. Likewise, the information desk attendant is not called on to do in-depth reference work, but only general and simple reference. In fact, the information desk reference collection typically is small, about a dozen or so volumes.

In short, the primary function of an information desk is location and orientation. Directions regarding the library and its basic finding tools are also of concern. Such tasks require a friendly, courteous person with a good knowledge of a particular library and a general knowledge of basic finding tools. A professional librarian is not required, unless detailed library instruction and reference service is provided.

\section{SUMMary}

Not all large libraries have information desks; about one-half of the academic libraries and one-third of the public libraries represented in this survey do not. In these libraries, the directional, instructional, and simple reference functions are performed by other library units, most frequently the reference or circulation department.

TABLE 7

Staffing Patterns During Evenings and on Weekends

\begin{tabular}{lcc}
\hline \hline & $\begin{array}{c}\text { Academic Libraries } \\
(N=48) \\
\text { Number (Percent) }\end{array}$ & $\begin{array}{c}\text { Public Libraries } \\
(\mathbf{N}=30) \\
\text { Number (Percent) }\end{array}$ \\
\hline Professional Librarian & $26(54)$ & $20(67)$ \\
High Level Nonprofessional & $6(12)$ & $8(27)$ \\
Low Level Nonprofessional & $2(4)$ & $2(7)$ \\
Student Assistant & $3(6)$ & - \\
Information Desk Not Staffed & $11(23)$ & - \\
\hline
\end{tabular}


In those libraries which do have information desks, approximately half of the information desk work involves directional and locational assistance. Almost all of the work can be subsumed under the categories of directional and locational assistance, instruction in the use of the library and its materials, and simple reference. Information desks in academic libraries perform more instructional services than do their counterparts in public libraries. About $40-45$ percent of the work is considered to be professional in nature.

The information desk is most frequently staffed by a professional librarian (in about two-thirds of the cases). Academic libraries staff the desk with a professional librarian more often during the day than during evenings and on weekends. On the other hand, public libraries tend to increase slightly the professional coverage during evenings and on weekends. Respondents were about equally divided as to whether or not a professional librarian on call (but not actually stationed at the desk) would be sufficient professional coverage.

On the average, information desks in academic and public libraries are staffed about the same number of hours per week: $65-70$ hours. However, since academic libraries remain open more hours per week than do public libraries, their ratio of "hours information desk is staffed to hours library is open" is smaller.
Regarding library structure and information desks, a significant correlation was found between information desks and decentralized reference. Presumably, when reference is decentralized, a point of contact must be established in order to provide directional assistance, referral of the patron to the right subject area reference, etc. A rather surprising finding was that two-thirds of the academic libraries and nearly half of the public libraries with information desks have, in addition, a general reference desk. Half of the public libraries and one-fourth of the academic libraries also staff a catalog assistance desk. Thus, the following combination can be found: decentralized reference areas, an information desk, and a general reference or catalog assistance desk. Apparently heavy patron use and/or special characteristics of individual libraries lead to these patterns.

In conclusion, whether or not a large library establishes or continues an information desk depends largely on how well the directional, instructional, and/ or simple reference functions are being served or can be served by other units in the library. If an information desk is established its staffing patterns and its hours of operation must be decided in response to local needs. However, this survey may provide some guidance by indicating the patterns of information desk service (or its absence) in other libraries.

\section{REFERENCEs}

1. Jane P. Kleiner, "Information Desk: The Library's Gateway to Service," CRL 29:496501 (Nov. 1968).

2. Six additional public libraries responded but could not be used in the study since they had no large central library in their system.

3. Eleanor F. Steiner-Pray and Helaine Mackeigan, comps., 1970-1971 American Library
Directory (New York: R. R. Bowker, 1970).

4. Larry Harrelson, Shirley Pelley, and Christine Gilson, "Final Report of a User Survey of the Bizzell Memorial Library with Special Reference to Problems" (Norman: University of Oklahoma libraries, July 1972). (Mimeographed) 